STATE OF ILLINOIS

DEPARTMENT OF REGISTRATION AND EDUCATION

DIVISION OF THE

NATURAL HISTORY SURVEY

STEPHEN A. FORBES, Chief

Vol. XIII. BULLETIN Article VI.

\title{
SOME RECENT CHANGES IN ILLINOIS RIVER BIOLOGY
}

BY

STEPHEN A. FORBES

and

ROBERT EARLE RICHARDSON

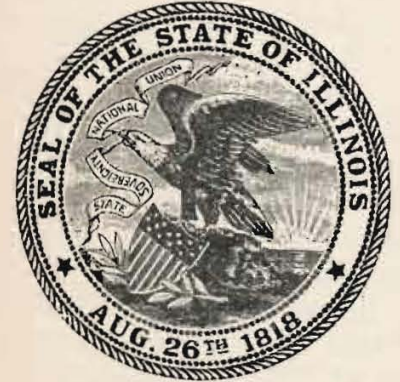

PRINTED BY AUTHORITY OF THE STÁTE OF ILLINOIS

URBANA, ILLINOIS

April, 1919 


\section{ERRATA}

Page 97, line 17, for first larval read pupal.

Page 112, in legend, for jonessi read jonesii.

Page 114, in legend', for or read of.

Page 125, line 4, for Bonosa read Bonasa.

Page 131, in legend, for hirundinaceus read hirudinaceus.

Page 138, last line, for coccoon read cocoon.

Plate XII, explanation page, next to last line, for acrivora read aerivora.

Plate XIII, explanation page, next to last line, for White-grubs read White-grub.

Page 293, Figure $5 a$ was reversed in printing, and the two items of the legend should change places.

Page 515, second table, for Pelocoris femorata read Pelocoris femoratus. 
Article VI.-Some Recent Changes in Illinois River Biology.* BY Stephen A. Forbes and Robert Earle Richardson.

The principal causes of change in the biological environment of the Illinois River which have come in since 1899 are the opening of the drainage canal of the Sanitary District of Chicago in January, 1900, a great increase in the amount of Chicago sewage emptied into the stream, and an extensive reclamation of the river bottoms for agricultural uses; and it is our present purpose to trace the principal effects of these changes upon the life of the stream. Although this study has had primarily a purely scientific motive, it has bearings of a practical character which we have followed out in some cases beyond the boundaries of our proper inquiry, with a view to making our results available, or at least suggestive, to those who have to deal with problems of sewage disposal, fisheries, bottom-land agriculture, and the like.

The principal changes due to the three causes above mentioned are presented summarily in the following numbered sections:-

1. The opening of the drainage canal of the Sanitary District of Chicago, January $1 \%, 1900$, admitted a flow of sewage-laden lake water which greatly increased the average depth and flow of the Illinois and lengthened the period and extended the range of its overflows. During the ten years preceding 1900 the average flow of the river at Peoria, 110 miles down-stream, was 8,391 cubic feet per second (or "second feet") †; but the flow of the sanitary canal alone in 1913 averaged $7,193 \mathrm{sec}$. ft., or 85.7 per cent. of the Peoria flow of the original river. $\$$

If we take account of some $600 \mathrm{sec}$. $\mathrm{ft}$. of Lake Michigan water coming into the Illinois River by way of the old Illinois and Michigan Canal, which is, of course, additional to the contribution of the sanitary canal, we have left $7, r 91 \mathrm{sec}$. $\mathrm{ft}$. as the average flow from the natural watershed of the stream above Peoria during the decade just preceding 1900. Combining the increments from the two canals, we find just half the average Peoria flow derived in 1913 from Lake Michigan.

At average low water of the above-mentioned decade just preceding 1900 , the flow at Peoria was only $1 \%$ per cent. that of the canal in 1913 , and at the lor'est rate of discharge $(\tau 23 \mathrm{sec} . \mathrm{ft}$.) it was only 10.5 per cent. At the highest water of the period on the other hand, the canal, if open at the time, would have increased the flow of the stream by less than 10 per cent. The ratio of canal to river water at the lowest river level was over eight times that at the highest. The effect of the canal upon the rising river is therefore to hasten the onset of the overflow and to increase the area greatly in the beginning, but this effect diminishes as

* The present brief paper is an abstract only of some of the more general and significant parts of the product of a long series of studies of the biology of the Jllinois River and its dependent waters which will be reported in detail in a number of articles now in course of preparation.

+ Jacob A. Harman, in the Report of the Illinois State Board of Health on Sanitary Investigations of the Illinois River Tributaries, in 190 ?. p. 37 .

$\ddagger$ Alvord and Burdick, Report on the lllinois River and its Bottom-lands (1915), 
the river continues to rise and it does not greatly expand the overflow when at its highest. It may thus materially increase the length of the overflow period without adding greatly to the area finally covered. All these effects of the canal affluent diminish, of course, down-stream, as the normal flow of the river is increased by the addition of tributary waters; and at the mouth of the river, in times of flood, less than 6 per cent. of the present flow of the stream comes from the sanitary canal. The biological importance of this extension of overflow conditions will be more clearly seen when we discuss the sources of supply of the river plankton.

We have shown, in an earlier paper, that the average depth of the Illinois River at Havana, 173 miles below the mouth of the sanitary canal, was about three feet greater during the 10 -year period following upon the completion of the canal than during the 10 -year period immediately preceding; and Alvord and Burdick, comparing the gage readings for fourteen years after and ten years before the opening of the canal, make this difference five feet for Peoria and three feet for Grafton, at the river's mouth.*

Not quite all this increase in depth can be fairly attributed to canal water, for the rainfall was somewhat less in the drainage basin of the Illinois during the earlier of these two periods than during the later. The average for the part of the state north of the mouth of the Illinois River was 34.09 inches per annum for the ten years from 1890 to 1899 , and 35.92 inches for the period from 1900 to 1909 . The rainfall for the $10-$ year period just preceding the opening of the canal was 1.83 inches per annum less than in the next ten years. $t$

If, however, we compare Havana levels from $18 \% 9$ to 1899 inclusive, with those of the ten years next following, we find the average for the above twenty-one years to be 6.9 feet, and that of the ten years from 1900 to 1909 to be 9.7 feet-an increase at that point of 2.8 feet fairly attributable to the canal.

2 . This greater volume of water throughout the year has also produced a greater expanse and depth of the bottom-land lakes, which commonly stand at about the level of the river itself. This fact is well illustrated by the change in Thompson Lake, near Havana-one of the largest lakes of the Illinois River series-as shown by two published tables of lake levels and corresponding differences of area, for the summer months (June to September) of thirty-four years, from 1874 to $190 \%$ inclusive $\neq$ From the first of those tables we learn that the average level of the lake for twenty-six summers preceding 1900 was 429.46 feet above the sea, and that for the eight years next following this average was 433.06 feet $\S$

* Alvord and Burdick's Report, p. 28.

$\dagger$ The data for this comparison were obtained from an article on the "Climate of Illinois," by Prof. J. G. Mosier, published as Bulletin No. 208 of the University of Illinois Agricultural Experiment Station.

$\ddagger$ Report of the Submerged and Shore Lands Legislative Investigating Committee, Vol. I., p. 171 . gage.

$\S$ These levels are equivalent to $5.09 \mathrm{ft}$. and $8.69 \mathrm{ft}$, respectively, on the Havana 
-a difference of 3.6 feet in the summer depth of the lake due to the opening of the sanitary canal; and we further find, by comparing these lake levels with the areas of the lake at different depths, as shown by the second of the tables, that the summer expanse of the lake averaged 1,943 acres before 1900 , and $5,0 \% 2$ acres since 1899 - an increase of more than two and a half times in the area of this lake, due to the higher levels produced by the canal.

Average Levels of Thompson Lake,
June, July, August, and Septedber,
1874-1907

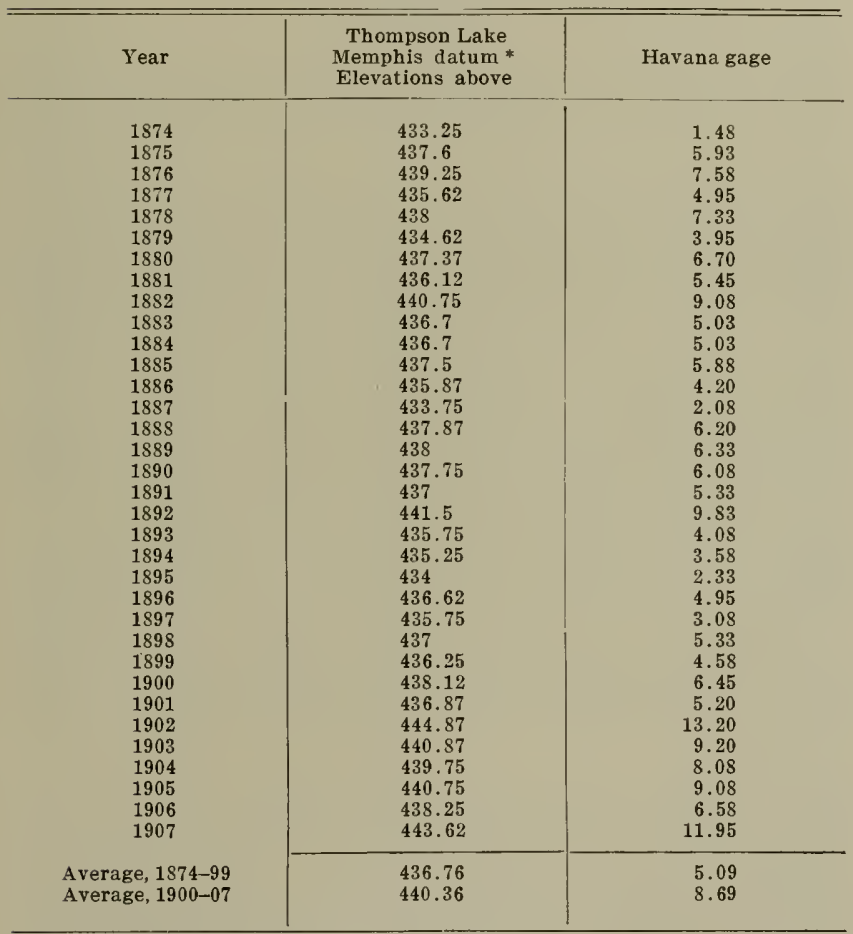

" "Memphis datum" is 7.3 feet below sea-level. 
INCREASED ACREAGE OF THOMPSON LAKE CORRESPONDING TO INCREASING LEVELS

\begin{tabular}{r|r}
\hline \hline As levels increase from- & $\begin{array}{c}\text { Area of lake increases, for each } \\
\text { tenth of a foot, by- }\end{array}$ \\
4.41 to 5.13 feet & 4.72 acres \\
5.13 to 6.08 " & 8.68 " \\
6.08 to 7.08 " & 15.48 " \\
7.08 to 8.08 " & 3.56 " \\
8.08 to 9.08 " & 3.79 " \\
9.08 to 10.08 " & 1.56 " \\
10.08 to 11.08 " & \\
\hline
\end{tabular}

3. A secondary effect has been to narrow permanently the belt of shallow weedy water along the banks of the stream in midsummer, and to do the same, at least temporarily, along parts of the shore of many of the lakes. The river waters now commonly reach in midsummer to the bases of the willows, permanently covering new banks of steeper slope than the original margins, which latter have now generally beconte too deeply submerged and too much shaded for rooting water-plants. Some of the lakes have lost large areas of rooted vegetation in the deeper parts, permanently, as it appears, while many others whose characteristic vegetation was killed out by the deeper water after the opening of the drainage canal, are now filling up again with the typical plants of deeper standingwater. This destruction of inshore and alongshore vegetation has been especially conspicuous in the broad belt of deadened trees and shrubs along the banks, especially in the middle course of the stream from Peoria southward. Other important effects are beginning to appear as these dead trees weaken and fall into the water of the stagnant lakes, fouling them, in the hottest weather, with the products of vegetable decay.

4. The greater depth of the present river, and especially the greater depth at low-water stages, must have an effect to diminish ranges of temperature, especially in the upper shallower part of the stream. The water there can not heat up as rapidly as formerly when exposed to the midsummer sun, or reach so high a temperature-a fact which must retard decomposition processes now as compared with the period before 1900 , and thus delay the transformation of sewage materials into forms fit for use as food for the normal plants and animals of an unpolluted stream.

5. Along with the greater average volume of the strean goes necessarily an increased average rate of flow and a shortening of the time of passage of water from point to point and from the source to the mouth. This difference is greatest for the lowest stages of water and least for the highest, but our computations show that, at usual midsummer levels, only about half the time is needed for water to flow the length of the stream that was taken before the opening of the canal, about thirteen 
days being sufficient for the passage from Utica to Grafton (230 miles) in the month of August in the years 1910-18, and an average of twentynine days in the same month of the years 1890-99.

This fact has many interesting consequences. Decomposition and assimilation processes set up at a given point and proceeding at a given rate are now extended farther down stream than formerly, and those which were usually completed at the mouth of the river before may now be only about half finished at that point. A plankton organism, if carried continuously by the main current, has much less time to multiply in the Illinois than formerly and reaches smaller numbers, and, other things being equal, it is proportionately less likely to be devoured on the way, the difference in this respect being the same as if the river were shortened by about one-half. Disease germs brought into the stream with sewage may now be carried as far again downward before they perish, and the sewage itself, imperfectly transformed before, as shown by chemical tests, now escapes from the river in still earlier stages of average transformation.

Of course neither plankton organisms nor any part of the water of the stream are actually carried the full distance down the main current, but everything is retarded more or less as it approaches the bottom or the shores. We have no data to show what the general average movement of the whole content of the river now is or how it compares with the former average rate of progress, but there can be no doubt of the general truth of the foregoing statement.

6. The sewage load of the river has greatly increased since 1899 . This is a necessary inference from the growth of Chicago and the river towns and the completion of the intercepting sewer along the lake front turning into the canal all sewage formerly sent into Lake Michigan, and it is shown also by a comparison of chemical data. The chlorine content of a polluted water (mainly chloride of sodium or common salt) is the best chemical index to the degree of its contamination by sewage, since the chlorine compounds pass down stream virtually undiminished and unchanged, while the nitrogen is rapidly transformed, and presently drawn upon as food for plants. A comparison of the amounts of chlorine passing Averyville, just above Peoria, before 1900 and in 1914, gives us $21 / 4$ times as much per second for the latter period.*

$\%$. Notwithstanding the increase in the quantities of sewage coming. into the river from Chicago, the flow of the stream has been increased in so much larger a ratio that the water of the river contained in 1914 a smaller percentage of sewage than before 1900 . The sewage of the stream had become much more dilute than formerly.

The ratio of chlorine (parts per million) in the water passing Lockport, 35 miles from Lake Michigan, in 189 -99 compares with that of 1914 as .3 to 1 , and the corresponding chlorine ratios for these periods at Averyville, 126 miles farther down, were as 2.3 to 1 .

* The chlorine average at Averyville July to October, in $1897-1899$, was $7.69 \mathrm{kjlo-}$ grams per second; in 1914 it was 17.31 kilograms per second. 
8. Owing to the much greater volume of the main stream since 1899 , the effect of tributary waters is now much less than before, whether this be the diluent effect of a cleaner stream than the Illinois, such as the Fox at Ottawa, or the polluting effect of a local inflow of sewage from one of the river towns, as at Pekin or Peoria. For the same reason these diluent effects are much less obvious and important at a high stage of water than at a low stage. Peoria sewage, for example, can not now pollute the stream at any time nearly as much as it formerly did when the river was low.

9 . The present greater average depth of the stream and the consequent lower average temperature must retard somewhat the rate of spontaneous chemical change by which the proteid compounds of the raw sewage, quite unfit in that condition to serve as food for chlorophylbearing plants, become converted by successive steps into forms fit for assimilation by green plants-into free ammonia, nitrites, and nitrates, in sequence-and must carry these stages of change farther down the stream than formerly; and this effect is to be added to that due to a virtual doubling of the rate of the down-stream movement.

10. As a consequence of several of the foregoing considerations it follows that the uppermost part of the river was more heavily charged with organic matter before 1900 than in 1914, and this headwaters pollution diminished rapidly downwards, the river returning to practically normal conditions much farther up-stream.

11. In our eariier paper it was shown that the tumbling of the water over the dam at Marseilles had a marked effect in 1911 to increase the content of dissolved oxygen, the additional oxygen being obtained, of course, from the air mixed with the water by the fall; and it was also shown that this increase of oxygen differed with the stage of water in the stream, being greatest when the river was low and the head of the falls was consequently highest. From this it follows (although we have no data on the influence of the dams before 1900) that this oxygenating effect must have been greater at the relatively low stages of that period than it is now. The removal of the upper dams, especially that at Marseilles-a measure strongly advocated in the interests of navigationwould have the effect to carry the polluted waters farther down-stream and to postpone their renovation both in distance and time.

12. It is also obvious, from what has already been said, that the organic contents of the sewage, unfit, as they are delivered to the stream, to serve at once as food. for its normal clean-water animals and plants, must become first available to them farther down-stream than before, and that, as a consequence, such normal organisms will find themseives excluded, at least at times of greatest poliution, from parts of the upper river where they have previously found food. Just how far down-stream this change of conditions has progressed is a question difficult to answer exactly, especially as we have no collections of aquatic plants and animals from the upper river made before 1900 in a way to bring them into comparison with those made by us since that date and thus to give us direct 
evidence on this point; but to come to conclusions it is only necessary to assume that chlorophyl-bearing organisms presently arrive in the river whenever conditions appear favorable to their maintenance and multiplication, an assumption warranted by all our studies, and those of others, upon the river and elsewhere and at other times. Such conditions occurred in their earlier phases between Lockport and Morris before 1900 at low water; but in 1911 not until somewhere between Marseilles and Spring Valley; while optimum conditions for green plankton apparently occurred at or above LaSalle before 1900 , but in 1911 not much if any above Chillicothe, and in 1918 not much above Peoria.

More recent evidence of a still continued gradual creeping downstream of pollutional conditions is found by comparison of collections made in 1911 with those obtained in August, 1918. In the former year a foul-water fungus (Sphaerotilus natans) disappeared from both channel and shore at or near Starved Rock, while August 28 to 30,1918 , it was found in the river at Henry, 35 miles below Starved Rock, and also at Lacon, 6 miles still farther down. At Henry, it was quite healthy, with normal cell-division in progress.

Other evident indications are given by collections of two Lake Michigan diatoms (Tabellaria flocculosa and T. fenestrata), which come into the river through the sanitary canal. In 1910 these clean-water plants managed to survive in small numbers, as they passed down-stream, but were always of a pallid, sickly color until they reached Chillicothe, and here the water was clean enough to permit their return to normal condition and to a rapid rate of multiplication; while in August, 1918, their numbers declined steadily down-stream, until at Pekin they disappeared almost completely.

Another Lake Michigan diatom (Melosira granulata var. spinosa) which lived through the worst pollution of 1910 and began to multiply at Spring Valley, does not now do so until it passes Chillicothe, 36 miles farther down.

13. Consistenly with the foregoing statements, the ratios of total nitrogen, whether expressed by parts per million or as kilograms per second, now escaping into the Mississippi River are larger than they were in 1899. The nitrogen ratio at Grafton in 1899 was to that of 1914 as 1 to 1.60 in the spring months (April to June), and as 1 to 1.26 in the summer months (July and August); and in kilograms per second these ratios in 1899 were to those of 1914 as 1 to 3.46 in spring and as 1 to 4.83 in summer: In other words, between 1899 and 1914 the total nitrogen in a given quantity of the river water was increased by about one-fourth in spring and by six-tenths in summer, while the total for the cutire flow of the stream in a giz'n time was, in spring, 31/2 times as great in 1914 as in 1899 , and in summer about 4.8 times as great. The nitrates, on the other hand, at the mouth of the river were, in parts per million, as 1 in 1899 to 1.48 in 1914 . It would seem from this that the nitrogen-consuming organisms have not increased in quantity since 1899 as fast as their food supplies. 
14. These food supplies show increase not only at the mouth of the river, where they are no longer available to the organisms of the stream itself, but also in the middle course of the Illinois, where its principal fisheries are found. The sum of the nitrates in spring, summer, and fall was greater in this part of the river in 1914 than in 1899-at Havana by 46 per cent., at Beardstown by 39 per cent., and at Meredosia by 40 per cent.

15. That this greater food supply has restulted in a greater production of plant and animal life in the stream was to be expected, and such evidence as we have supports this expectation. As we have shown in the earlier paper already cited, the larger plankton organisms of the Illinois River at Havana in 1909 and 1910 surpassed in quantity to the cubic meter of water that of 1897 and 1898 by 69 per cent., and surpassed the average production of the three years from 1895 to 1898 by 135 per cent., while the like plankton of 1909 and 1910 from Quiver Lake, a bay opening broadly into the river at all stages, surpassed that of the earlier period by 218 per cent. Furthermore, collections of the animal forms of the river bottom, so made at many points down the course of the stream as to give the number of specimens to a square yard, show us that the richness of the plankton and that of the bottom sediments rise and fall together, the part of the river containing the largest number of organisms from one containing the largest number from the other also. We consequently have reason to believe that the bottom organisms, from which many animals, fishes especially, obtain an important part of their food, are more abundant now than before 1900 .

It is to be noted, however, that these foregoing data of plankton production were obtained at a time (August, 1909, to August, 1910) when only about 25,000 acres of bottom-land were under levee, and that this area has now been increased some five or six fold; and it will presently be shown that plankton production must be expected to fall off rapidly with the draining of lakes and a reduction of the area of overflow. It is quite possible, therefore, that the increased plankton production due to the increase of sewage has now been lost as a' result of reclamation operations.

16. The area in the Illinois bottom protected by levees from overflow and thus reclaimed for agriculture, increased between 1899 and 1914 from 6,700 acres to 124,205 acres, and there were at the latter date 47,250 acres more in drainage districts whose levees were not finished at that time. When these newer districts are completely leveed and drained, the original area of overflow of every spring will be reduced by 39 per cent., and that subject to overflow at the high-water level of 1904 will be reduced by 42 per cent. The effect of this restriction of overflow upon some of the tendencies due to the opening of the sanitary canal must be considerable. The river will now rise higher than before in times of flood and will fall lower when rainfall is deficient, but the floods will run off more rapidly since the leveed areas which were formerly flooded will no longer help impound the waters of the overflow, giving them up gradually to the stream. 
Owing to the confinement of flood waters within narrower bounds, all effects of greater depth and swifter flow of the stream must be intensified. The bottom sediments are now more forcibly scoured out and moved farther down-stream than formerly: the successive stages of the oxidation and assimilation of sewage proteids are carried farther downward, as is also the upper limit of the normal life of the stream; the plankton is transported more swiftly and continues a shorter time in the Illinois, multiplying there, consequently, to smaller numbers; and more of the food material of the Illinois escapes into the Mississippi unconsumed.

Moreover, drainage of contributing lakes and swamps and narrowing of the area of overflow lessens the productivity of the river itself quite independently of the richness of its waters in the elements of fertility. A river and its plankton are a flowing soil and its crop, both slipping away continuously, but both renewed constantly from an exhaustless source of supply. The fertility of the flowing water at any time is not dependent on the fertility of that which has preceded it, but on materials of fertility brought into it from the watershed. A complete exhaustion of this flowing soil by "overproduction" would not impoverish, but would actually enrich the organisms depending on it, for they could avail themselves of its entire product without penalty of subsequent starvation.

As the plankton of a river system is carried down-stream, its progeny are carried with it, and, however numerous they may become, they can have no upstream effect on the population. If the running wafer were left wholly to itself, the river would speedily empty itself of plankton; to maintain the floating population there must be a constant source of supply outside the waters involved in the downward moventent. Such a supply can be found only in places where aquatic organisms are virtually stationary, or from which, to say the least, they do not escape until they have themselves begun to multiply, and in which, consequently, they will leave fertile descendants behind them. Such places of possible continuous origin of the plankton organisms are weedy waters along shore, sluggish shoals, eddies, bays, sloughs, open backwaters of the bottom-lands, and lakes connecting with the stream. The river plankton originates in the mere overflow of the stationary population in such breeding places, and the reduction of these sources of supply must have its proportionate effect on the river product. Hence, the plankton productivity of the stream does not depend primarily on the richness and extent of its own flowing waters, but on those of its subsidiary breeding grounds, and if these are not adequate to the maintenance of a plankton sufficient to consume all the readily available food materials of the stream, more or less fertility of the current waters must go to waste.

It is conceivable, of course, that stagnant and semi-stagnant tributary waters might be so productive and so extensive as to contribute to the river a rapidly multiplying population sufficient completely to exhaust the food supply borne by the ruming water within the limits of its own course, however fertile it might be, sending it out at the mouth of the 
stream with all the elements of its fertility strained out; but such a selfcontained and self-sufficient system is far from anything we actually find, and there must be a heavy loss of potential productivity at the mouth of every normal stream.

It may be noted, however, that a river, notwithstanding its continuous losses, may actually maintain a heavier plankton than a lake; even where both derive their food materials from the same source, as from the waters of a spring flood. The river being continuously fertilized while the lake has only the fertility left to it when the flood subsides, if the former has a slow current, as in low water, and a long course, its plankton may multiply to a number which the fixed fertility of the lake can not maintain.

\section{Effects on the Fisheries}

The apparent effects upon fish production of some of the environmental changes here discussed were treated in considerable detail in 1913 in our paper on the biology of the upper Illinois River. In this it was shown that the fishes normal to the river were virtually driven out of it during the midsummer low water of 1911 and 1912 by pollutional conditions extending as far down as Ottawa, 34 miles from the source, and that it was not until Hennepin was reached, 32 miles still farther down, that the fish population of the river was made up of substantially the same species as were to be found farther down. It was, however, in the Henry-Chillicothe section of the river, $r \%$ to 93 miles down-stream, that the relative numbers of the several species first became virtually normal, and that all ichthyological effects of the Chicago contamination had obviously disappeared.

After the above paper appeared we compiled statistics of production for the whole river from every available source, and these were placed, in 1915, at the disposal of Alvord and Burdick, civil engineers, who were making at the time for the Rivers and Lakes Commission of the state an extensive study of the Illinois River and its bottom-lands with special reference to problems of fisheries, agriculture, and flood control. Their report on the status and possibilities of the river fisheries embodies substantially all our information bearing on the subject at the time, and we find their reasoning convincing and their conclusions sound. Our objects and point of view are, however, somewhat different from theirs, and we find it necessary to develop some parts of the discussion more fully than was done by, them in their report.

That the actual harvest of the Illinois River fisheries was greatly increased from 1900 to 1908 as compared with the yield from 1894 to 1899 is shown by statistics collected by the Illinois Fishermen's Association, the Illinois State Fish Commission, and the U. S. Bureau of Fisheries; but that a marked decline of production followed, at least until 1913 , is made evident by data of shipments from Havana, one of the principal fishing points on the river, obtained by the junior author of this paper for the six years following $190 \%$. From 1894 to 1899 the 
yield of the river fisheries rose from $6,037,378$ pounds to $12,605,691^{*}$ pounds-with an average annual yield of approximately $8,900,000$ pounds ; and between 1900 and 1908 inclusive it rose from $11,899,865$ pounds to $21,583,000 *$ pounds, with an annual average of approximately $15,000,000$ pounds. The increase for the five years immediately preceding the opening of the sanitary canal was thus about 9 per cent. per annum, that for the 8 -year period following the opening was about 3.5 per cent. per annum, and the estimated decline for the next four years based upon statistics of production at Havana was at the rate of 15 per cent. per annum. The fisheries at this point yielded in fact 25 per cent. less in 1912 than they did in 1896; the gain made in the course of this period of sixteen years was more than lost before its close.

There are four factors to which this rise and fall of production may be attributed: 1 , the opening of the sanitary canal and the diversion of nearly all the Chicago sewage from lake to river; 2 , the rapid multiplication of the European carp, which by 1908 yielded $6 \pm$ per cent. of the whole product of the river fisheries; 3 , the great stimulus to fishing which this enormous increase of the carp produced; and 4, the rapid progress of reclamation operations from 1908 onward. The first three of these factors tended to increase the actual yield, but the last, a cause of decline, has more than overbalanced their joint effect. It is difficult to isolate these various factors in a way to distinguish their separate shares in this stimulus to production or the reverse, but something may be done in this direction by an examination of such statistics as are available.

The principal multiplication of carp came between 1894 and 1897 , when this fish rose in ratio from 9.6 per cent, to 56.5 per cent. of the entire catch from the river; and the carp continued in about this ratio of abundance until 1903 , when it stood at $5+.9$ per cent. Our next data are those for 1908, when the entire catch from the river, as given by the U. S. Bureau of Fisheries, was $24,000,000$ pounds, of which 64.4 per cent. were carp, the total yield of both carp and other fishes being more than twice that reported for any preceding year. The year 1908 was, however, so exceptionally favorable for fishing that its totals are misleading; but the rise in ratio of carp to other fish seems nevertheless correct.

It is evident that it is to the increase of carp more than to the influx of Chicago sewage that we must attribute the rise in production after 1894. From that year to 1899 (the period of rapid multiplication of carp) the fisheries' yield of the river increased 2.1 times, while by $190 \%$, seven years after the opening of the canal, it had risen only to $14, \gamma 39,000$ pounds - an additional gain of $1 \%$ per cent.

This latter increase may have been due to a greater food supply derived from the sewage, or it may have been simply a consequence of the growth of the fishing industry, which was greatly stimulated by the increase of the carp supply.

* The mean of the estimates of the U. S. Fish Commission and of the Illinois Fishermen's Association. 
As will be seen from the table on this page, the number of men engaged in fishing in the State of Illinois increased 42 per cent. between 1894 and 1899 (five years) and 86 per cent. between 1899 and 1908 (nine years), and the value of the fisheries equipnent increased 20 per cent. during the first period and 194 per cent. during the second. The value of the fisheries product, on the other hand, increased $15 \%$ per cent. and 151 per cent. during these two periods, respectively. We have no separate data for the Illinois River for 1894 or 1899 , but in 1908 more than half the fisheries of the state and nearly two-thirds of the capital employed in fishing were on that stream.

Statistics of Fishenies in Illinois, 1894-1908* PERCENTAGES OF INCREASE OR DECREASE

\begin{tabular}{|c|c|c|c|c|}
\hline & \multicolumn{2}{|c|}{$\begin{array}{c}\text { Between } \\
1894 \text { and } 1899\end{array}$} & \multicolumn{2}{|c|}{$\begin{array}{c}\text { Between } \\
1899 \text { and } 1908\end{array}$} \\
\hline & $\begin{array}{l}\text { Per cent. } \\
\text { increase }\end{array}$ & $\begin{array}{l}\text { Per cent. } \\
\text { decrease }\end{array}$ & $\begin{array}{l}\text { Per cent. } \\
\text { increase }\end{array}$ & $\begin{array}{l}\text { Per cent. } \\
\text { decrease }\end{array}$ \\
\hline 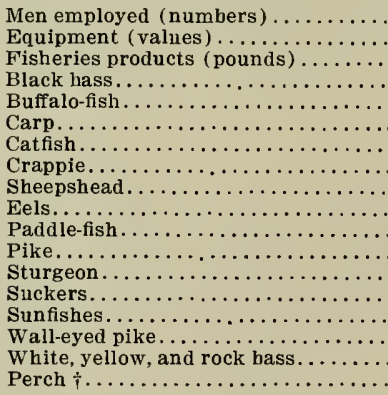 & 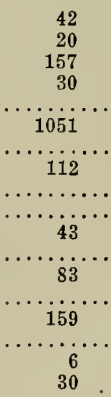 & 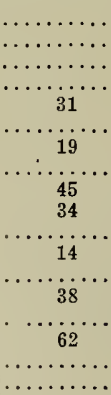 & $\begin{array}{c}86 \\
194 \\
151 \\
322 \\
119 \\
30 \\
260 \\
9 \\
6 \\
106 \\
\ldots \ldots \\
13 \\
8.5 \\
216 \\
\ldots \ldots \ldots \\
1040\end{array}$ & $\begin{array}{l}52 \\
92\end{array}$ \\
\hline $\begin{array}{l}\text { All native fishes } \ldots \ldots \ldots \ldots \ldots \ldots \ldots \ldots \\
\text { Bottom feeders } \ldots \ldots \ldots \ldots \ldots \ldots \ldots \ldots\end{array}$ & $\begin{array}{r}42 \\
\cdots \cdots\end{array}$ & $\because{ }_{29} \cdots$ & & $\begin{array}{r}11 \\
7\end{array}$ \\
\hline
\end{tabular}

* In 1908,57 per cent. $(2,500)$ of the fishermen of the state and nearly twothirds $(\$ 551,000)$ of the capital employed, were on the Illinois River. $\dagger$ Mostly from Lake Michigan district.

A comparison of the percentages of increase and decrease in the two periods covered by the above table, one of five years and the other of nine, shows that the average rate of increase per annum in number of men was a little greater in the second period than in the first, and that of equipment was more than five times as great; but that, nevertheless, 
the rate of increase in the product of the fisheries was but little more than half as great in the second period as in the first. In other words, the product of the fisheries fell far short of keeping pace with the increase in men and means devoted to fishing. This fact indicates that the stream was being "over-fished" during the second of the above periods, and that its yield must consequently be expected eventually to fall off if fishing operations are continued on the same scale as in the years just preceding 1909.

This "diminishing return" for increasing activity is seen especially in the yield of European carp, as was to be expected in view of the recent introduction of this fish into waters especially favorable to its growth and multiplication; but it is also seen in the yield of the natize species, which after increasing at an average annual rate of 8 per cent. for the first or five-year period, diminishcd about 1 per cent. per annum during the second period. That is, the rapidly growing abundance of carp so stimulated fishing operations that the stock of native fishes was too heavily drawn upon and began to dwindle in yield. We see this particularly in the species which are distinguished as bottom-feeders-the buffaloes, the suckers, the sturgeon, the sheepshead or drum, and the catfishes.* Taken together these diminished in yield about 6 per cent. per annum during the first period, and nearly 1 per cent. during the second.

In comparing these two periods, account should be taken of the fact that 1908 was an especially favorable year for fisheries, and its yield was far the greatest ever known on the Illinois River. In that year the fishing season, which begins with July and extends to November, was one of low water, concentrating the fish in relatively close quarters, and giving easy access to the fishing grounds, and this fishing season had been preceded by a long period of unusually high water, covering nearly all of $190 \%$ and the early months of 190 s, during which the fishes had a wide range over shallow waters filled with an abundant food supply. The consequence was a fisheries yield 50 per cent. greater than the average of the five years next preceding of which we have records, viz., 1899 , $1900,1903,1906$, and $190 \%$; and to make a just comparison between our two periods in respect to increase or decrease of yield the yield of 1908 should be diminished by one-third. If this be done, the ratios will stand as tabulated on page 15 .

Along with an enormous multiplication of the carp in 1894 to $189 \%$ the yield of native fishes fell off in the Illinois River by 22.2 per cent. (from $5,45 \pi, 731$ pounds to $4,234,308$ pounds); * but from 1900 to $190 \%$ it increased by 56 per cent. In other words, as the number of carp increased the number of native fishes diminished before the opening of the sanitary canal at an average rate of ; per cent. per annum; and after the opening of the canal, the number of carp remaining virtually constant. the supply of native fishes increased in seven years by an average of 8

- The yield of these bottom-feeding species in 1894, when the number of carp was as yet relatively insignificant, was 81 per cent. of the total yield of native fish.

* Alvord and Burdick, Fig. 25. 
Percentages of INCRease or Decrease between 1899 AND 1908 (ADJUSTED)

\begin{tabular}{|c|c|c|}
\hline & $\begin{array}{l}\text { Per cent. } \\
\text { increase }\end{array}$ & $\begin{array}{l}\text { Per cent. } \\
\text { decrease }\end{array}$ \\
\hline Fisheries products (pounds) ....... & 68 & \\
\hline 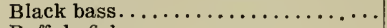 & 181 & \\
\hline 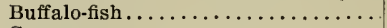 & & 47 \\
\hline 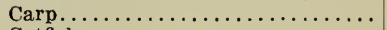 & 46 & \\
\hline 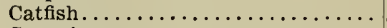 & & 13 \\
\hline Crappie.................. & 14 & \\
\hline 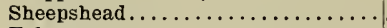 & $\ldots \ldots \ldots$ & 27 \\
\hline Eels $\ldots \ldots \ldots \ldots \ldots \ldots \ldots \ldots \ldots$ & $\ldots \ldots \ldots$ & 30 \\
\hline Paddle-fish . . . . . . . . . . . . . & 37 & \\
\hline Pike.................... & $\ldots \ldots \ldots$ & 60 \\
\hline 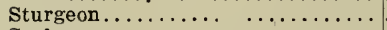 & $\ldots \ldots \ldots$ & 25 \\
\hline 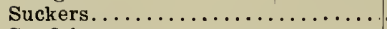 & & 28 \\
\hline 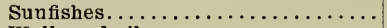 & 110 & \\
\hline Wall-eyed pike.............. & $\ldots \ldots \ldots$ & 67 \\
\hline White, yellow, and rock hass....... & $\ldots \ldots \ldots$ & 94 \\
\hline Perch $\ldots \ldots \ldots \ldots \ldots \ldots \ldots \ldots$ & 695 & \\
\hline All native fishes. . . . . . . . . . . & 79 & \\
\hline 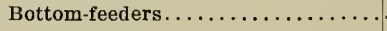 & & 37 \\
\hline
\end{tabular}

per cent. per annum-a condition of things not easily understood except on the hypothesis that the resources of multiplication and subsistence opened up by the canal had enabled the native river fishes not only to sustain themselves but to increase in number in the face of the tremendous competition of a quantity of carp greater than that of all the other fishes of the river taken together.

To what extent, if at all, it was the great and increasing quantity of organic material brought into the river by the canal which was the cause of increasing fish production, or whether the cause was mainly or wholly an expansion of the area of shallow water in which fishes could breed and feed to the best advantage, is a question to which we are unable to make definite answer; but it is certain that it is now the area of available breeding and feeding grounds, and not the food supply, which is the limiting factor in the yield of the Illinois River fisheries. The raw materials of food sufficient for a much greater volume of plant and animal life than the river and its dependent waters now contain, are being continuously poured into the stream and worked up to the chemical conditions required for their assimilation; but they pass out of the river at its mouth in increasing quantities unassimilated because, owing. to the progressive diking of bottom-lands and draining of lakes, the productive area is steadily diminishing. From the report of Alvord and Burdick it appears that up to 1899 the area of the bottom-lands under completed levees was but 9,100 acres; five years later it had risen to 21,500 acres; by 1908 , the year when the fisheries data of the last national census were collected, to 
54,850 acres; by 1913 , when our own last data of fish production were obtained, to 130,830 acres; and a year later, when Alvord and Burdick prepared their report, to 145,780 acres. Furthermore, there were at this time about 50,000 acres in drainage districts proposed or already formed, in which the work was in various stages of advancement, besides 7,755 acres concerning the condition of which our information is incompletea total of 200,000 acres of Illinois River bottom-lands covered by levee districts acually complete or in immediate prospect four years ago.

The land area overflowed by the extraordinary high water of 1904 amounted to 280,910 acres, and if we add to this 49,340 acres in bottomland lakes at low-water stages, we have a total of 330.250 acres, outside the area of the stream itself, formerly covered by water in time of flood. From $4 \pm$ per cent. of this area the fishes of the river were already permanently excluded in 1914 , and another 16 per cent. will be added to it as soon as the drainage projects then in hand or in immediate view are completed.

Coincident with this restriction of their range the yield of fishes declined, as shown by our data of shipments from Havana from 1908 to October, 1913, as shown in the following table.

Total Fish Catch, H.AFaya Market

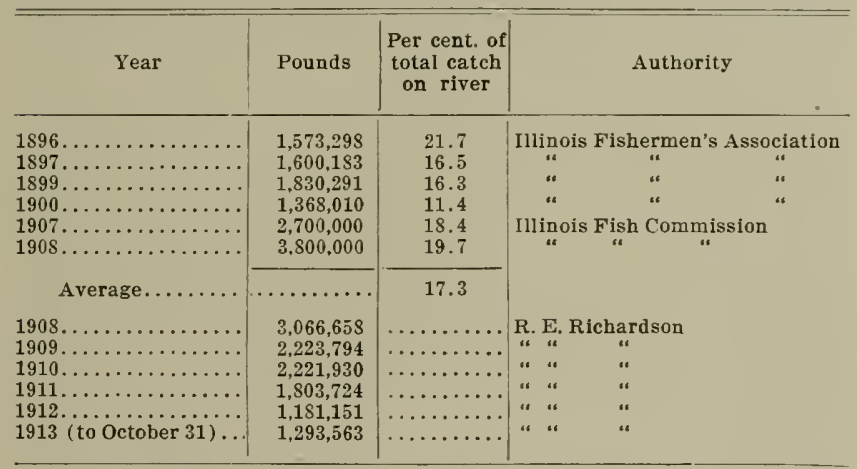

Nоте.-1,593,000 pounds average 1896 to 1900 inclusive.

All the facts indicate that the relation here shown is one of cause and effect-that the yield of fishes is diminished, in the face of a greatly increased and rapidly growing supply of the raw materials of their food, because of the narrowing of the backwaters, which are for the river important places of digestion and assimilation in which the organic wastes of the city and of the land are worked up into forms fit for food for the higher animals. It is not only space but time also that is now lack- 
ing, since the river now hurries its burden downward at a rate more rapid than it did before it was shut out from so large a part of its valley.

This correlation of production with the area of overflow is well brought out by Alvord and Burdick in the following diagram showing the relation, from 1894 to 1914 , between the yield of fishes from the Illinois, on the one hand, and the area of the river valley which was under water for half the year or more on the other.

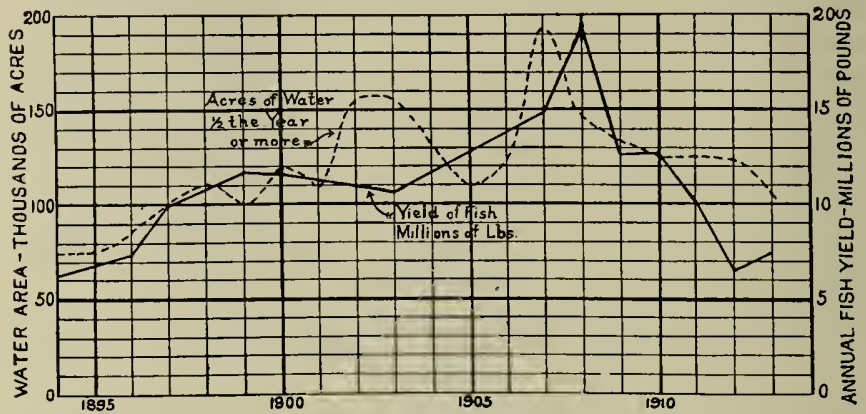

-That the various important changes in the river environment should take unequal effect on the various species of fish, is of course to be expected. Those most sensitive to pollution will be the first to disappear from the upper river as pollution increases and the last to reappear as one goes down the stream. As the river fisheries are now directed chiefly to the catching of carp, native fishes of similar range and habits to the carp are most likely to be taken in excessive numbers and to dwindle year by year as a consequence; and as the ratio of shallow alongshore water to the deeper parts of the river and lakes is diminished by diking and draining of bottom-lands, the species which feed and breed alongshore will feel the effects of the change most deeply. In our collections of 1911 and 1912 a single minnow known as the shiner (Notropis atherinoides) was especially notable for its indifference to pollution, and this was the only fish found in the main current in midsummer, in more than accidental frequency, as far up the stream as Marseilles, 26 miles from the source. A number of other species were taken at this place, it is true, below the dam, but only at the mouths of small tributaries which were diluting the river water with a cleaner flow. At Ottawa, 34 miles from the source, single specimens of gizzard-shad, red-horse, and European carp were taken from the undiluted river among i9 fishes captured in various ways, 69 of which, however, were the shiner above mentioned. At Starved Rock (42 miles), the black bullhead and the large-mouthed black bass were added to the list, and at Hennepin (66 
miles) the short-nosed gar, the dogtish or bowtin, the common sucker, the speckled hullhead (Ameiurus nebulosus), the bluegill sunfish, the black crappie, and the wamouth (Chaenobryttus) were represented by one to three specinens each in hauls which gave us lit European carp. The common perch, both the crappies, and the large-mouthed black bass began to appear in some numbers at Depue $(60$ miles $)$, but not in their normal ratio much above Chillicothe ( 93 miles).* The larger and more voracious game fishes, such as the wall-eyed pike and the pickerel, which had disappeared above Peoria, seem never to have been normally abundant in the Illinois. The most notable species whose numbers have fallen off greatly of recent years in the main middle course of the stream (Pekin to Meredosia) are the shovel-fish or spoonbill cat. the buffalo-fish, and the sheepshead or drum.

On the whole, the general nake-up of the river population of fishes has been surprisingly little affected by any of the recent events here discussed excepting, of course, the introduction of the European carp.

\section{Investliation Neenew}

The total effect of reclamation operations upon the important fisheries of the Illinois is so serious as to call for a careful study of the possibilities of prevention and remedy : and this is the conclusion reached by Alvord and Burdick in their report to the Rivers and Lakes Commission. After calling attention to the fact "that the fishery of the Illinois Rives. is more valuable than that of any other fresh-water river fishery in the United States, and is exceeded only by the Great Lakes and the salmon industry of the Pacific coast," and that, owing mainly to reclanation operations, the yield of the river has lately been reduced to abont a third that previously reported, they say: "It would seem, however, that there is prospect of a good profit by intelligent fish culture in the ponds and water courses remaining within the levee districts, provided that the industry is carried on as an adjunct to farming in much the same way that poultry is ordinarily raised upon the farm. This would utilize a water acreage that otherwise could produce no revenue and could serve no useful purpose except to store the flood waters in the course of passige to the drainage ditches. If the fishery is to remain commercially important. means must be provided to take the place of the breeding grounds formerly furnished by the shallow waters of the lakes and sloughs which have been reclaimed.

* * * * * * * * * *

"It is believed, notwithstanding the levee districts present and future, that a scientific utilization of the remaining public waters, including the river and twenty or more meandered lakes, together with the best use of the remaining undiked bottons and the spaces between the river banks and levee toes, will result in the maintenance of a valuable fishery. We

* The fleld party already referred to, which nade the survey of the river from Hennepin to Peoria in August and September, 1918, saw no signs of fishes in the river at either Hennepin or Henry, and were told by fishermen that none had been seen for a long time at either place. Al tacon one had been occasionally noticed in the river channel. 
recommend that the State Laboratory of Natural History * be empowered to investigate and determine the best means for promoting the fishery interests in the public waters and the adjacent undiked lands. IVe should hope that a practical program might be worked out that would permit of great help to the fisheries and at the same time provide game and fish preserves, usable by the public under proper restrictions."

Such an investigation should include problems relating to both public and private waters, the former comprising the river and its principal tributaries and the bottom-land lakes which are not protected by levees and are hence subject to overflow, and the latter the lakes within levee districts which lay too low or were in part too deep for profitable drainage. There are serious difficulties connected with the utilizing of these last-mentioned waters, owing to the fact that they are, as a rule, mere mud-holes, without shallow margins and with bottons deep with an almost impalpable ooze. Only intelligent experiment can show whether they can be so dredged as to give them bottoms of reasonably firm consistency, and whether, by adjacent excavation, fertile shallows can be created as breeding grounds for adult fishes and feeding grounds for the fry. That the condition of the river and meandered lakes could be greatly improved by carefully considered management as a public fisheries property there can be little doubt, but the problem of methods of operation and policies to be adopted in such a case is a new one, for the solution of which there are no precedents. As a fisheries property the waters of the state are an unsubdued and neglected wilderness, and the investigator in this field must be prepared to do a pioneer work.

* Now the State Natural History Survey. 